\title{
Pengaruh Pendekatan Saintifik Terhadap Hasil Belajar Siswa Pada Mata Pelajaran Pendidikan Agama Islam di SD Negeri 19 Talang Kelapa
}

\author{
Nazifa Liana \\ Fakultas Ilmu Tarbiyah \& Keguruan \\ Universitas Islam Negeri Raden Fatah Palembang \\ nazifa_liana@yahoo.co.id
}

\begin{abstract}
Abstrak: Penelitian yang berjudul" pengaruh pendekatan saintifik dalam meningkatkan hasil belajar siswa pada mata pelajaran Pendidikan Agama Islam di SD Negeri 19 Talang Kelapa Kecamatan Talang Kelapa" ini dilatar belakangi oleh, proses mengajar guru masih menggunakan sistem tradisional dan bagaimana hasil belajar belajar siswa. Dari sisi metodologi, penelitian ini merupakan penelitian eksperimen dengan Postest-Only Control Design. Data penulis peroleh dari observasi, dokumentasi, tes, populasi dalam penelitian ini adalah seluruh siswa, yang terdiri dari kelas V B dan kelas V C yang seluruh jumlah 50 orang. Dari hasil analisis data dapat disimpulkan bahwah hasil belajar Pendidikan Agama Islam di SD Negeri 19 Talang Kelapa terkatagori sedang. Ini terlihat bahwah ada 5 orang (10\%) tergolong tinggi, 30 0rang $(60 \%)$ yang tergolong sedang, dan 15 orang $(30 \%)$ tergolong rendah. Terakhir terdapat pengaruh yang signifikan antaran pendekatan saintifik terahadap hasil belajar Pendidikan Agama Islam di SD Negeri 19 Talang Kelapa baik pada tarif signifikan 5\% maupun pada taraf signifikan 1\% sebesar $0,273(0,472) 0,354$. Dengan kata lain Ha penelitian yang berbunyi terdapat penggunaan pendekatan saintifik terhadap hasil belajar Pendidikan Agama Islam diterima sedangkan Ho ditolak.
\end{abstract}

Kata Kunci: pendekatan saintifik, hasil belajar

Abstract: The study is entitled "the influence of the scientific approach in improving students' learning achievement in the subject of Islamic Religion at SDN 19 Talang Kelapa." This study was triggered by the teaching process which still used traditional systems and by the students' learning achievement. In terms of methodology, this research is an experimental study with Postest-Only Control Design. The research data were obtained from observation, documentation, and tests. The population in this study were all students, which consisted of class V B and class V C which totaled 50 students. From the results of data analysis, it can be concluded that the results of learning Islamic Religion in SDN 19 Talang Kelapa, are categorized medium. This can be seen from the indicators that 5 students $(10 \%)$ had high learning achievement, 30 students (60\%) had medium learning achievement, and 15 students (30\%) had low learning achievement. Finally, there was a significant influence of the scientific approach on the students' learning achievement in learning the subject of Islamic Religion at SDN 19 Talang Kelapa both at a significant degree of $5 \%$ and at a significant degree of $1 \%$ at $0.273(0.472) 0.354$. In other words, $\mathrm{Ha}$ that says there is a significant influence of a scientific approach to students' learning achievement in the subject of Islamic Religion is accepted, and $\mathrm{Ho}$ is rejected.

Keywords: Scientific Approach, Learning Achievement

\section{Pendahuluan}

Pendidikan merupakan salah satu hal yang penting bagi kehidupan manusia, karena dengan pendidikan manusia diarahkan untuk mengembangkan potensi dan kemampuan yang dimilikinya untuk menghadapi persoalan-persoalan yang dihadapinya. Pendidikan juga dapat menjadikan manusia menjadi berkualitas dan berakhlak mulia (Abdullah Idi, 2013: 125). Pendidikan Seiring dengan peningkatan dan perkembangan teknologi di era globalisasi, pendidikan memegang peranan yang sangat penting dalam peningkatan kualitas SDM, mulai dari pendidikan dasar hingga perguruan tinggi. Karena hanya 
SDM yang berkualitas yang bisa bersaing dalam era globalisasi. Melalui pendidikan seseorang akan memperoleh ilmu yang akan mereka butuhkan. Tujuan utama dari pendidikan adalah untuk meningkatkan kualitas sumber daya manusia dan menghasilkan generasi yang berpendidikan. Mutu pendidikan dapat ditingkatkan dengan berbagai cara yaitu melalui kurikulum yang efektif, metode-metode pembelajaran yang efisien dan strategi belajar yang menarik minat belajar siswa.

Menurut Tim penulis Panduan Direktorat Pembinaan Sekolah Dasar (kemendikbud, 2016: 1) Undang-Undang Nomor 20 Tahun 2003 tentang Sistem Pendidikan Nasional, Pasal 1 ayat 1 menyatakan bahwa " pendidikan adalah usaha sadar dan berencana untuk mewujudkan suasana belajar dan proses pembelajaran agar peserta didik secara aktif mengembangkan potensi dirinya untuk memiliki kekuatan spiritual keagamaan, pengendalian diri, kepribadian, kecerdasan, akhlak mulia serta keterampilan yang diperlukan dirinya, masyarakat, bangsa dan negara". Untuk mencapai pendidikan Nasional, maka proses pendidikan yang dilaksanakan di Sekolah Dasar (SD) harus membekali anak didik dengan kualitas spiritual keagamaan, sikap positrif terhadap masalah kebangsaan dan kenegaraan, pengetahuan, keterampilan, serta akhlak mulia yang diperlukan sebagai dasar kokoh untuk membangun karakter anak bangsa yang berkeadaban (Kemendikbud, 2016:1).

Pendidikan Agama Islam sebagai salah satu dari sekian banyak rumpun mata pelajaran di sekolah yang mempunyai peranan penting dalam pembentukan watak dan pembinaan bangsa. Pendidikan Agama Islam dilakukan untuk mempersiapkan peserta didik meyakini, memahami, dan mengamalkan ajaran Islam (Zakiah Drajat, 1992: 57). Tujuan pendidikan agama Islam adalah untuk membentuk manusia yang mengabdi kepada Allah, cerdas, terampil, berbudi pekerti yang luhur, bertanggung jawab terhadap dirinya dan masyarakat guna tercapainya kebahagiaan dunia akhirat (Akmal Hawi, 2005: 51).

Dalam pengembangan kurikulum 2013, pelaksanaan pembelajaran berbasis kompetensi dan karakter dianjurkan untuk menggunakan pendekatan ilmiah atau disebut pendekatan santifik. Pendekatan ilmiah atau saintifik adalah pendekatan pembelajaran yang dirancang agar siswa aktif mengkonstruksi konsep, prinsip atau teori melalui tahapan-tahapan mengamati, menanya, menalar, mengumpulkan informasi/mencoba, menganalisis data dan menarik kesimpulan (mengasosiasi) dan mengomukikasikan konsep, prinsip atau teori yang ditemukan (Kemendikbud, 2016: 21). Pendekatan saintifik terdiri dari lima tahap yaitu mengamati/observasi, bertanya, melakukan percobaan, asosiasi (menghubungkan/menalar), membangun jejaring (Ridwan Abdullah Sani, 2015: 53). Dengan pembelajaran saintifik tidak harus dilakukan mengikuti prosedur yang kaku, namun dapat disesuaikan dengan pengetahuan yang hendak dipelajari.

Kurikulum 2013 adalah upaya pemerintah untuk meningkatkan mutu pendidikan. tujuan Kurikulum 2013 mengarah pada peningkatan kompetensi seimbang antara sikap, keterampilan, dan pengetahuan. Ketiga kompetensi tersebut didukung 4 pilar yaitu produktif, kreatif, inovatif, dan afektif (Ridwan Abdullah Sani, 
2015: 45). Pengembangan kurikulum baru memberikan banyak perubahan, tidak hanya standar kompetensi lulusan saja yang diubah tetapi standar isi, standar proses, dan standar penilaian ikut diubah. Proses pembelajaran pada Kurikulum 2013 diubah dengan mengamanatkan pendekatan saintifik/ilmiah yang diterapkan secara tematik terpadu dalam pembelajaran.

Bila merunjuk wancana di atas, kurikulum 2013 keberhasilannya sangat tergantung pada kesiapan guru sebagai ujung tombak pendidikan. Pada kurikulim 2013 pendidikan ditekankan pada student centries (berpusat pada siswa), siswa dituntut untuk aktif menggali informasi, menemukan sendiri dan guru hanyalah sebagai fasilitator, tapi bila kita lihat pada pendidikan saat ini, anak didik terkesan pasif, mereka hanya mendengar, mencatat dan mengerjakan apa yang diperintahkan oleh guru, dan kalau mau jujur mengapa siswa pasif, tidak antusias, mungkin penyebabnya siswa kurang menyukai pembelajaran yang sedang berlangsung, atau bisa jadi proses belajar mengajar yang terjadi antar siswa dan guru tidak menarik sehingga siswa tidak antusias mengikuti pembelajaran.

Tugas utama guru adalah bagaimana membuat proses belajar mengajar menjadi menarik, bagaimana siswa menyukai pembelajaran apalagi pembelajaran pendidikan agama Islam, karena tidak bisa kita pungkiri pendidikan agama Islam adalah ruh bagi pendidikan itu sendiri, dan lebih parahnya lagi, setali tiga uang dengan perkembangan pendidikan anak didik, tenaga pendidik yang sangat berperan dalam proses belajar mengajar pun mengalami stagnan, cendrung mengalami kemunduran. Padahal salah satu kunci keberhasilan pelaksanaan kurikulum baru yang mulai diterapkan pada Juli 2013 (http:www.sekolahdasar.net diakses tgl 25 maret 2017).

Tugas utama guru adalah membelajarkan siswa, yaitu mengkondisikan siswa agar belajar aktif sehingga potensi dirinya (kognitif, afektif, dan psikomotorik) dapat berkembang dengan maksimal. Dengan belajar aktif, melalui partisipasi dalam setiap kegiatan pembelajaran, akan terlatih dan terbentuk kompetensi yaitu kemampuan siswa untuk melakukan sesuatu yang sifatnya positif yang pada akhirnya akan membentuk life skill sebagai bekal hidup dan penghidupannya. Agar hal tersebut di atas dapat terwujud. Guru semestinya mengetahui bagaimana cara siswa belajar dan menguasai berbagai cara mempelajarkan siswa, inilah yang menjadi eksistensi guru professional dibutuhkan untuk melakukan sebuah terobosan baru bagi proses pembelajaran siswa.

\section{Kajian Literatur}

Pendeketan adalah konsep dasar yang mewadahi, menginspirasi, menguatan, dan melatari pemikiran tentang bagaimana metode pembelajaran diterapkan berdasarkan teori tertentu (Hamruni, 2012: 6).. Oleh karena itu banyak pandangan yang menyatakan bahwa pendekatan sama artinya dengan metode. Pendekatan ilmiah berarti konsep dasar yang menginspirasi atau melatar belakangi perumusan metode mengajar dengan menerapkan karakteristik yang ilmiah. Pendekatan pembelajaran ilmiah (scientific 
teaching) merupakan bagian dari pendekatan pedagogis pada pelaksanaan pembelajaran dalam kelas yang melandasai penerapan metode ilmiah.

Pendekatan pembelajaran ilmiah menekankan pada pentingnya kolaborasi dan kerja sama di antara peserta didik. Pendekatan saintifik merupakan salah satu pendekatan pembelajaran ilmiah. mengungkapkan bahwa penerapan pendekatan saintifik bertujuan untuk pemahaman kepada peserta didik dalam mengenal, memahami berbagai materi menggunakan pendekatan ilmiah, bahwa informasi bisa berasal dari mana saja, kapan saja, tidak bergantung pada informasi searah dari guru. pembelajaran dengan pendekatan saintifik adalah proses pembelajaran yang dirancang sedemikian rupa agar peserta didik secara aktif mengkonstruksi konsep, hukum atau prinsip melalui tahapantahapan mengamati, merumuskan masalah, mengajukan atau merumuskan hipotesis, mengumpulkan data dengan berbagai teknik, menganalisis data, menarik kesimpulan dan mengkomunikasikan konsep, hukum atau prinsip yang ditemukan (Majid, 2014: 193).

Proses pembelajaran menyentuh tiga ranah, yaitu sikap, pengetahan, dan ketrampilan. Dalam proses pembelajaran berbasis pendekatan ilmiah, ranah sikap menggamit transformasi subtansi atau materi ajar agar peserta didik "tahu mengapa". Ranah ketrampilan menggamit transformasi subtansi atau materi ajar agar peserta didik "tahu bagaimana". Ranah pengetahuan menggamit transformasi subtansi atau materi ajar agar peserta didik "tah apa". Hasil akhirnya adalah peningkatan dan keseimbangan antara kemampuan untuk menjadi manusia yang baik (soft skill) dan manusia yang memiliki kecakapan dan pengetahuan untuk hidup secara layak (hard skills) dari peserta didik yang meliputi aspek kompetensi sikap, ketrampilan, dan pengetahuan. Dalam jurnal (Yulia Megawati, Fakultas Ekonomi Universitas Negeri Surabaya) Pembelajaran dengan pendekatan saintifik adalah proses pembelajaran yang dirancang sedemikian rupa agar peserta didik secara aktif mengkonstruk konsep, prinsip melalui tahapantahapan mengamati (untuk mengidentifikasi atau menemukan masalah), merumuskan masalah, mengajukan atau merumuskan hipotesis, mengumpulkan data dengan berbagai teknik, menganalisis data, menarik kesimpulan dan mengomunikasikan konsep, prinsip yang ditemukan . Pendekatan saintifik termasuk pendekatan yang kreatif dan inovatif, menjadikan siswa yang diberi tahu menjadi siswa yang mencari tahu, dari guru yang merupakan sumber belajar menjadi belajar dari beraneka macam sumber, dari pendekatan tekstual menuju proses sebagai penguatan penggunaan pendekatan ilmiah.

Pendekatan saintifik atau pendekatan ilmiah ini memerlukan langkah-langkah pokok sebagai berikut (Hosnan, 2014: 37):

1. Observasi (Mengamati)

2. Questioning (Bertanya)

3. Associating (Menalar)

4. Experimenting (mencoba)

5. Communicating (mengkomunikasikan) 
Jurnal I Md. Eri Ariawan Pembelajaran pendekatan saintifik adalah proses pembelajaran yang dirancang sedemikian rupa agar peserta didik secara aktif mengkontruksi konsep, hukum atau prinsip yang "ditemukan". Pendekatan saintifik dimaksud untuk memberikan pemahaman kepada peserta didik dalam mengenal, memahami berbagai materi menggunakan pendekatan ilmiah, bahwa informasi bisa berasal dari mana saja, kapan saja, tidak bergantung pada informasi searah dari guru. Permendikbud No.81 A tahun 2013, menyatakan proses pembelajaran saintifik terdiri atas lima pengalaman belajar pokok.

Menurut Dimyati dan Mudjiono (1999: 3), "hasil belajar adalah hasil dari suatu interaksi tindakan belajar dan tindakan mengajar". Nana Sudjana (1999: 21) menyatakan "hasil belajar adalah kemampuan kemampuan yang dimiliki siswa setelah ia memiliki pengalaman belajarnya”.

\section{Metodologi Penelitian}

Jenis penelitian yang dilakukan ini menggunakan jenis penelitian kuantitatif dengan pendekatan kuantitatif, yaitu suatu penelitian yang dilakukan untuk meneliti peristiwa yang telah terjadi dan kemudian melihat kebelakang untuk mengetahui faktorfaktor yang dapat menimbulkan kejadian tersebut penelitian kuantitaif juga dapat diartikan sebagai metode penelitian yang berlandaskan pada filsafat positivisme, digunakan untuk meneliti pada populasi atau sampel tertentu, teknik pengambilan sampel pada umumnya dilakukan secara random, pengumpulan data menggunakan instrumen penelitian, analisis data bersifat kuantitatif/statistik dengan tujuan untuk menguji hipotesis yang telah ditetapkan.

Populasi ialah keseluruhan objek penelitian Sedangkan menurut Sugiyono populasi adalah wilayah generalisasi yang terdiri atas obyek/subyek yang mempunyai kualitas dan karakteristik tertentu yang ditetapkan oleh peneliti untuk dipelajari dan kemudian ditarik kesimpulannya. Adapun populasi dalam penelitian ini adalah keseluruhan siswa kelas V SDN 19 Talang Kelapa yang berjumlah 76 orang siswa. Sampel adalah sebagian atau wakil populasi yang diteliti. Teknik pengambilan sampel dalam penelitian ini adalah teknik cluster random sampling. Peneliti mengambil sampel dari kelas yang ada, sampel dari jumlah populasi dan diambil untuk menjadi sampel penelitian (Sugiyono, 2011: 121). Adapun sampel dalam penelitian ini adalah siswa kelas V SDN 19 Talang Kelapa yang terdiri dua kelas. Kelas V.B berjumlah 25 orang siswa dan kelas V.C 25 orang siswa jadi semuanya berjumlah 50 orang siswa. penelitian ini terdiri dari tiga variabel, dua variabel bebas satu variabel terikat. Di dalam penelitian yang dilakukan ini, menggunakan dua variabel, yaitu variabel $\mathrm{X}$ dan Y. Variabel X menjadi variabel pengaruh, yaitu penerapan pendekatan Saintifik dan variabel Y yaitu terpengaruh, yaitu hasil belajar siswa di SDN 19 Talang Kelapa. analisis data merupakan kegiatan setelah data dari responden atau sumber data lain terkumpul, kegiatan dalam analisis data adalah mengelompokkan data berdasarkan variabel dan jenis responden, menyajikan data tiap variabel yang diteliti, melakukan perhitungan untuk menjawab rumusan masalah dan melakukan perhitungan untuk menguji hipotesis 
yang telah diajukan.

Dalam penelitian ini penulis menggunakan analisis deskriptif kuantitatif. Sedangkan pengolahan data kuantitatif yaitu dengan membahas, menjabarkan dan menghubungkan fakta-fakta yang ada dan menarik kesimpulan secara deskriptif. Kemudian dari hasil tes data tersebut dianalisa dan diolah melalui program Statistical Prouct and Service Solution (SPSS) dan interpretasi

Teknik pengumpulan data adalah teknik atau cara-cara yang dapat digunakan oleh peneliti untuk mengumpulkan data. Metode (cara atau teknik) menunjuk suatu kata yang abstrak dan tidak diwujudkan dalam benda, tetapi hanya dapat dilihatkan penggunaannya melalui observasi, wawancara, pengamatan, ujian (tes) dokumentasi. untuk memastikan kesungguhan dan kepercayaan terhadap data yang telah dikumpulkan tersebut maka masih perlu dilakukan pengujian, pengujian yang dilakukan adalah uji validitas dan reliabilitas.

\section{Hasil dan Pembahasan}

Pelaksanaan proses belajar mengajar Pendidikan Agama Islam dengan menggunakan pendekatan saintifik di SD Negeri 19 Talang Kelapa ada lima tahap yaitu mengamati, menanya, menalar, mencoba dan mengkomunikasikan.

1. Mengamati

Kegiatan pertama adalah pendekatan ilmiah (scientific approach) adalah pada langkah pembelajaran mengamati/observing. Metode obsevasi adalah salah satu strategi pembelajaran yang menggunakan pendekatan kontestual dan media asli dalam rangka membelajarkan siswa yang mengutamakan kebermaknaan proses belajar.

Pada tahap mengamati siswa membaca dan memahami permasalahan yang ada di dalam buku materi Pendidikan Agama Islam yang diberikan bersama dengan teman sekelompoknya. Peneliti bertindak sebagai guru dalam hal ini menjelaskan bahwa siswa bersama dengan kelompoknya harus mengamati masalah yang ada di buku materi Pendidikan Agama Islam yang telah diberikan.

Kegiatan mengamati ini dilakukan pada tanggal 27 Agustus 2017, selanjutnya menggunakan media papan tulis dan gambar dalam menjelaskan materi puasa bulan ramadhan. Dalam kegiatan mengamati, dalam hal ini membuka secara luas dan bervariasi kesempatan peserta didik untuk melakukan pengamatan melalui kegiatan: melihat, menyimak, mendengar dan membaca dengan memfasilitasi peserta didik untuk melakukan pengamatan, melatih mereka untuk memperhatikan (melihat, membaca dan mendengar) hal yang paling penting dari suatu benda atau objek terutama mengenai materi puasa di bulan ramadhan.

Selanjutnya guru membuka kesempatan kepada peserta didik untuk bertanya mengenai apa yang sudah dilihat, disimak dan dibaca. Kesimpulan penulis proses pembelajaran melalui tahapan mengamati bermanfaat bagi peserta didik yaitu peserta didik memperoleh pengalaman langsung dari proses kegiatan yang dilakukan peserta didik, pemenuhan rasa ingin tahu peserta didik, sehingga proses pembelajaran memiliki kebermaknaan tinggi. Selain itu, peserta didik dapat menemukan fakta bahwa ada 
hubungan antara objek yang dianalisis dengan materi pembelajaran yang sudah dijelaskan.

\section{Menanya}

Kegiatan belajar menanya adalah mengajukan pertanyaan tentang informasi yang tidak dipahami dari apa yang diamati atau pertanyaan untuk mendapatkan informasi tambahan tentang apa yang diamati (dimulai dari pertanyaan faktual sampai kepertanyaan yang bersifat hipotetik. Proses pembelajaran menanya guru pendidikan agama Islam dikelas $\mathrm{V}$ yaitu menyampaikan materi tentang puasa di bulan ramadhan. Sebagaimana yang telah di sampaikan Permendikbud Nomor 81a Tahun 2013 kegiatan menanya adalah kegiatan menanya adalah mengajukan pertanyaan tentang informasi yang tidak dipahami dari apa yang diamati atau pertanyaan untuk mendapatkan informasi tambahan tentang apa yang diamati.

\section{Menalar}

Kegiatan pembelajaran menalar sebagaimana yang disampaikan permendikbud nomor 81a Tahun 2013 adalah memproses informasi yang sudah dikumpulkan, baik terbatas atau hasil kegiatan mengumpulkan/ eksperimen maupun hasil dari kegiatan mengamati dan kegiatan mengumpulkan informasi.

Tahapan menalar yang dilakukan peserta didik kelas VC secara berkelompok mengumpulkan data dari buku bacaan, dan teman kelompok tentang puasa bulan ramadhan. Setelah data terkumpul peserta didik mendiskusikan dengan teman kelompok dari kegiatan menalar tersebut peserta didik membuat media pembelajaran sesuai dengan kreatifitas kelompok seperti membuat peta konsep. Kesimpulan penulis menalar digunakan dalam pendekatan saintifik karena untuk menemukan keterkaitan informasi satu dengan yang lainnya, menemukan pola dari informasi tersebut. Sehingga dalam kegiatan menalar ini peserta didik dapat mengembangkan sikap jujur, teliti, disiplin, tata aturan, kerja keras, kemampuan menerapkan prosedur dan kemampuan berpikir induktif serta deduktif dalam menyimpulkan.

\section{Mencoba}

Tahapan mencoba dilakukan peserta didik kelas VC secara berkelompok mengumpulkan data dari buku bacaan, dan teman kelompok tentang puasa bulan ramadhan. Setelah data terkumpul peserta didik mendiskusikan dengan teman kelompok dari kegiatan mencoba tersebut peserta didik membuat media pembelajaran sesuai dengan kreatifitas kelompok seperti membuat peta konsep.

\section{Mengkomunikasikan}

Kegiatan berikutnya adalah menuliskan atau menceritakan apa yang ditemukan dalam kegiatan mencari informasi, mengasosiasikan dan menemukan pola. Hasil tersebut disampikan di kelas dan dinilai oleh guru sebagai hasil belajar peserta didik atau kelompok peserta didik tersebut. Kegiatan "mengkomunikasikan" dalam kegiatan 
pembelajaran sebagaimana disampaikan dalam permendikbud Nomor 81a Tahun 2013, adalah menyampaikan hasil pengamatan, kesimpulan berdasarkan hasil analisis secara lisan, tertulis atau media lainnya.

Dalam kegiatan mengkomunikasikan kelas VB dan kelas VC materi puasa di bulan ramadhan. Peserta didik mengkomunikasikan secara berkelompok didepan kelas. Dalam kegiatan tersebut setiap kelompok berbeda ketika presentasi di depan kelas ada yang menggunakan media gambar dan ada juga yang hanya menjelaskan dengan kreativitas membuat peta konsep. Ketika peserta didik presentasi guru memberikan penilaian yang terkait dengan penilaian sikap dan keterampilan.

Berdasarkan pengamatan penulis yang bertindak sebagai guru dalam menyimpulkan kegiatan mengkomunikasikan bertujuan untuk melatih peserta didik untuk berkreatifitas dan mengembangkan sikap jujur, teliti, toleransi, kemampuan berpikir sistematis dan berani menyampaikan ide yang telah didiskusikan dengan singkat dan jelas serta mengembangkan kemampuan bahasa yang baik dan benar.

Sebelum tes disebarkan kepada seluruh responden, dilakukan uji coba tes dengan menyebarkan soal kepada 50 siswa sebagai sampel penelitian. Uji coba ini dilakukan dengan menguji tingkat validitas dan reliabilitas pertanyaan-pertanyaan yang diajukan dalam penelitian, butir pertanyaan dikatakan valid jika angka $r$ lebih besar dari 0,3, sedangkan suatu alat pengukur dikatakan reliable (andal) adalah bila alat pengukur tersebut mampu memberikan pengukuran sesuai dengan apa yang telah diukurnya dan sejauh mana alat pengukur tersebut sama dengan dirinya sendiri (consistency). uji validitas tes menunjukan nilai cronbach's alpha masing-masing pertanyaan lebih besar dari $r$ tabel $5 \%$ atau 0,514. Hal ini dapat berarti bahwa data dalam variabel penggunaan pendekatan saintifik dalam meningkatkan hasil belajar siswa pada mata pelajaran PAI di SD Negeri 19 Talang Kelapa mempunyai nilai yang valid.

Untuk mengetahui reliabilitas data yang diperoleh, dilihat dari nilai Cronbach Alpha setiap variabel yang dibandingkan dengan nilai koefisien yang telah ditetapkan. Hasil pengolahan data primer dengan menggunakan SPSS, dapat dilihat pada dalam tabel berikut ini :

\begin{tabular}{|c|c|c|}
\hline Variabel & Cronbach Alpha & Keterangan \\
\hline Penggunaan Pendekatan Saintifik & 0,890 & Reliabel \\
\hline Hasil Belajar Siswa & 0,943 & Reliabel \\
\hline
\end{tabular}

Berdasarkan hasil uji reabilitas diatas, menunjukkan bahwa nilai koefisien Cronbach Alpha lebih besar dari 0,6. Dengan demikian, instrumen setiap pernyataan untuk semua variabel yang dinyatakan adalah reliabel.

Hasil dari analisis melalui uji descriptive statistics frequencies pada program SPSS menunjukkan bahwa skor tes hasil belajar kognitif siswa berasal dari responden sebanyak 50 siswa, diperoleh nilai rata-rata sebesar 72,5, standar deviasi (simpangan baku) sebesar 3,884, nilai terendah 65, nilai tertinggi 85 dan jumlah sebesar 2175 . 


\begin{tabular}{|l|l|l|l|l|}
\hline No & \multicolumn{1}{|c|}{ Kategori Skor } & Rentang Nilai & \multicolumn{1}{|c|}{ Frekuensi } & \multicolumn{1}{|c|}{ Presentase } \\
\hline 1 & Tinggi & 14 ke-atas & 5 & $10 \%$ \\
\hline 2 & Sedang & $12-13$ & 30 & $60 \%$ \\
\hline 3 & Rendah & $11-$ ke-bawah & 15 & $30 \%$ \\
\hline & & & $\sum f=50$ & $100 \%$ \\
\hline
\end{tabular}

Berdasarkan tabel di atas dapat diketahui bahwa hasil belajar siswa pada mata pelajaran PAI di SD Negeri 19 Talang Kelapa dengan menggunakan pendekatan saintifik skor tinggi dengan rentang nilai 14-15 sebanyak 5 orang atau $10 \%$, skor sedang dengan rentang nilai 12-13 sebanyak 30 orang atau $60 \%$, dan skor rendah dengan rentang nilai 11-10 sebanyak 15 orang atau 30\%. Jadi dapat disimpulkan bahwa hasil belajar siswa termasuk kategori sedang sebesar $60 \%$.

Hasil dari analisis melalui uji descriptive statistics frequencies pada program SPSS menunjukkan bahwa skor tes hasil belajar kognitif siswa berasal dari responden sebanyak 50 siswa, diperoleh nilai rata-rata sebesar 72,5, standar deviasi (simpangan baku) sebesar 3,884, nilai terendah 65, nilai tertinggi 85 dan jumlah sebesar 2175 . Berdasarkan persentase skor tes hasil belajar dapat diketahui bahwa hasil belajar siswa pada mata pelajaran PAI di SD Negeri 19 Talang Kelapa dengan menggunakan pendekatan saintifik skor tinggi dengan rentang nilai 14-15 sebanyak 5 orang atau $10 \%$, skor sedang dengan rentang nilai 12-13 sebanyak 30 orang atau $60 \%$, dan skor rendah dengan rentang nilai 11-10 sebanyak 15 orang atau 30\%. Jadi dapat disimpulkan bahwa hasil belajar siswa termasuk kategori sedang sebesar 60\%. Berdasarkan koefisien determinasi $\left(\mathrm{R}\right.$ square $=\mathrm{r}^{2}$ ) sebesar 0,223, merupakan kuadrat koefisien korelasi 0,472. Artinya, sebesar 22,3\% besarnya hasil belajar siswa pada mata pelajaran Pendidikan Agama Islam ditentukan dengan penggunaan pendekatan saintifik, sedangkan sisanya sebesar 78,7\% ditentukan oleh faktor lain.

\section{Kesimpulan}

Dari hasil analisis, maka penulis dapat mengambil suatu kesimpulan terhadap penelitian ini, yaitu sebagai berikut: Penggunaan pendekatan saintifik dalam proses belajar mengajar Pendidikan Agama Islam di SD Negeri 19 Talang Kelapa. Dalam proses pembelajaran guru sudah menggunakan pendekatan saintifik yang terdiri dari 5 tahapan yaitu: mengamati, menanya, mengeksplorasi, menalar/ mengasosiasi dan mengkomunikasikan. Hasil belajar peserta didik pada mata pelajaran Pendidikan Agama Islam sebesar $60 \%$ di SD Negeri 19 Talang kelapa termasuk katagori sedang. Hal ini terlihat berdasarkan standar deviasi bahwa 5 orang (10\%) tergolong tinggi, 30 0rang $(60 \%)$ yang tergolong sedang, dan 15 orang $(30 \%)$ tergolong rendah. Ada pengaruh yang signifikan antaran pendekatan saintifik terahadap hasil belajar Pendidikan Agama Islam di SD Negeri 19 Talang Kelapa baik pada tarif signifikan 5\% maupun pada taraf signifikan $1 \%$ sebesar $0,273(0,472)$ 0,354. Dengan kata lain Ha penelitian yang 
berbunyi terdapat penggunaan pendekatan saintifik terhadap hasil belajar Pendidikan Agama Islam diterima sedangkan Ho ditolak. 


\section{Daftar Pustaka}

Andayani, D. (2005). Pendidikan Agama Islam Berbasis Kompetensi: Konsep dan Implementasi Kurikulum 2004. Bandung: Remaja Rosdakarya.

Arikunto, S. (2006). Prosedur Penelitian: Suatu Pendekatan Praktik. Jakarta: PT Rineka Cipta.

Daryanto. 2010. Media Pembelajaran Peranannya Sangat Penting Dalam mencapai Rineka Tujuan Pembelajaran. Yogyakarta: Gava Media.

Hawi, A. 2005. Kapita Selekta Pendidikan Islam. Palembang: IAIN Raden Fatah Press

Sani, A.R. (2014). Pembelajaran Saintifik untuk Implementasi Kurikulum 2013. Jakarta: Bumi Aksara. 
